\title{
Ordu (Altınordu) kenti parklarının kullanıcı memnuniyeti açısından irdelenmesi*
}

\author{
Kübra Nur BEYLi $\left(D_{1}\right.$, Murat YEşí $\mathbb{D}^{1}$ \\ ${ }^{1}$ Ordu Üniversitesi, Ziraat Fakültesi, Peyzaj Mimarlığı Bölümü, Ordu
}

\begin{abstract}
*Bu çalışma, Doç. Dr. Murat YEŞİL danışmanlığında yürütülen Kübra Nur BEYLİ'nin “Ordu kenti parklarının peyzaj mimarlığı açısından irdelenmesi" isimli yüksek lisans tezinden üretilmiştir.
\end{abstract}

Alınış tarihi: 9 Temmuz 2019, Kabul tarihi: 25 Ekim 2019

Sorumlu yazar: Murat YEŞiL, e-posta: muraty25@hotmail.com

\section{Öz}

Yapılaşmanın giderek arttığı günümüz kentlerinde doğadan uzaklaşmakta olan kentliler tekrar doğaya yakınlaşmak adına açık ve yeşil alanlara yönelme eğilimi göstermektedir. Bir kentin yeşil alan sisteminin en küçük birimlerinden biri olan mahalle parkları, kentlilerin rekreasyon amaçlı öncelikli tercihleri arasında yer almaktadır. Bu yüzden mahalle parklarının; mahallenin karakteristik özelliklerine, nüfus büyüklügüne ve özelliklerine göre planlanması, mahalle sakinlerinin günlük rekreasyon ihtiyaçlarını karşılayacak alan kullanımları ve donatılar içerecek şekilde tasarlanması gerekmektedir. Bu çalışma ile Ordu kenti, Altınordu ilçesinde bulunan parkların kullanıcıların beklentilerini ne düzeyde karşıladıklarını belirlemek amaçlanmıştır. $\mathrm{Bu}$ kapsamda 173 kişi ile bire bir anket uygulaması yapılarak kullanıcıların en çok hangi parkı kullandıkları, memnuniyet düzeyleri ve parklarda karşılaştıkları olumsuzluklar tespit edilmiştir.

Anahtar kelimeler: Altınordu, Rekreasyon, Park, Kullanıcı Memnuniyeti

The determination of Ordu (Altınordu) parks in terms of user satisfaction

\footnotetext{
Abstract

In today's cities where construction is gradually increasing, the urbanites who move away from nature tend to turn to open and green areas in order to get closer to nature. Neighborhood parks, which
}

are one of the smallest units of the green area system in the neighborhoods, which are the smallest settlements of a city, are among the priority preferences of the citizens for recreation purposes. In this context; The neighborhood parks should be organized according to the characteristic functions of the neighborhood, population sizes and characteristics, space uses and equipment to meet the daily recreation needs of the residents. The aim of this study is to determine the adequacy of the parks in the Altmordu district of Ordu city and to what extent they meet the expectations of the users. In this context, a one-to-one survey was conducted with 173 people to determine which park users use most, their satisfaction levels and the negativities they face in the parks. According to the survey results, it is seen that the coastal parks are preferred more by the users than the neighborhood parks because of the variety of activities they offer.

Key words: Altınordu, Recreation, Park, User Satisfaction

\section{Giriş}

Kentler, yerleşik hayata geçmiş olan insanların toplanma ve bir arada olma içgüdüleriyle ortaya koydukları, ihtiyaçlarına göre biçimlendirdikleri yaşama mekânlarını temsil etmektedir. Kentlerde görülen ekonomik gelişmeler doğrultusunda artan sanayileşme ve paralelinde gerçekleşen hızlı nüfus artışı kentlerin farklı şekillerde yenilenmesine ve değişmesine neden olmuştur. Bu değişim ile birlikte kentlerde görülen yüksek kazançlar kırsal alanda toplumsal parçalanmalara neden olmuş, köyden 
kente göç oranlarını arttırmış ve "kentleşme" olgusunu meydana getirmiştir (Kahraman, 2017).

Kentleşme olgusuyla birlikte kent yaşamının monotonluğundan ve yoğun iş temposundan bunalan insanların günlük streslerden uzaklaşmak ve dinlenmek için yapacakları etkinliklerin önemi daha da artmaktadır (Akova, 2012). İnsanların boş zamanlarında dinlendirici ve eğlendirici etkinlikler yapmaları anlamına gelen rekreasyonel aktivitelerin gerçekleştiği açık ve yeşil alanlara, özellikle kentsel mekanlarda büyük gereksinim duyulmaya başlanmıştır. Bu gereksinimler doğrultusunda açık yeşil alan sistemi içerisinde bulunan park alanları, aktif ve pasif karakterli olmak üzere insanların dinlenme, eğlenme, spor yapma gibi aktivitelerin gerçekleşmesine imkân sağlayan alanlar niteliği taşımaya başlamıştır.

Parklar kentsel yaşamın getirdiği birçok etkiyle doğadan uzaklaşmakta olan insanların tekrar doğaya yönelmelerine imkân sunan, peyzaj tasarım elemanları ile düzenlenmiş alanlardır (Nasuh, 1993). $\mathrm{Bu}$ alanlar, insanları fiziksel ve psikolojik yönden iyileştiren, toplumlar arasında bağı güçlendiren, yaşamak ve çalışmak için kentleri çekici hale getiren mekânlardır (Sherer, 2003).

Park alanları; rekreasyonel, sosyal, ekolojik, arazi organizasyonu, ekonomik yapılara göre şekillenmiş ölçülü, dengeli ve güzel kompozisyon ile oluşturulmuş alanlar niteliğindedir. Büyüklükleri ve etkili hizmet alanları, kullanımları, coğrafi özellikleri ve kullanıcı profilleri bakımından; milli parklar, bölge parkları, kent parkları, mahalle parkları, çocuk oyun alanları, spor alanları, hayvanat bahçeleri ve botanik parkları şeklinde sınıflara ayrılmaktadır (Gürsoy, 2018).

Mahalle parkları; kentlilerin rekreasyonel faaliyetlerini gerçekleştirdikleri, kent dokusu içerisinde geçiş alanı niteliği taşıyan en küçük yeşil alan birimidir (Ersoy, 1994). Park alanlarının yıl boyu kullanılacak şekilde alt ve üst yapı elemanlarına sahip olması gerekmektedir. Alanların drenajı, zemini içerisinde barındırdığı fonksiyonlar, kapasitesi, bakım ve hizmet üniteleri yıl boyu kullanımlara uygun şekilde donatılmalıdır (Kandemir, 2010). Kullanıcıların alanlardan etkin şekilde yararlanmaları adına parklardaki donatı elemanlarının Türk Standartları Enstitüsü (TSE) tarafından yürürlüğe konulan "Şehir içi yollar Kaldırım ve yaya geçitlerinde ulaşılabilirlik için yapısal önlemler ve işaretlemelerin tasarım kuralları" başlıklı TS 12576 standardına uygun olmalıdır. Bu standard, hareket kısıtlılığı bulunanlar dahil tüm yayaların, yaya yollarını ve kaldırımları, yaya geçitlerini ve kavşakları güvenli ve rahatça kullanabilmeleri için oluşturulacak yapısal önlemlerin ve işaretlemelerin tasarım kurallarını kapsamaktadır (Anonim, 2019).

$\mathrm{Bu}$ çalışma kapsamında; Ordu kenti, Altınordu ilçesinde bulunan parkların yeterlilikleri ve kullanıcıların beklentilerini ne düzeyde karşıladıklarının belirlenmesi amaçlanmıştır.

\section{Materyal ve Yöntem}

\section{Materyal}

Karadeniz Bölgesinde bulunan Ordu kenti; kuzeyinde Karadeniz, doğusunda Giresun, batısında Samsun, güneyinde Sivas ve Tokat illeriyle çevrilidir (Şekil 1). Ordu, Orta ve Doğu Karadeniz toprakları üzerinde bulunmakta olup, $40^{\circ} 41^{\prime}$ kuzey enlemleri ile $37^{\circ} 38^{\prime}$ doğu boylamları arasında yer almaktadır (Anonim, 2012). 19 ilçeden oluşan Ordu kentinin kent merkezini Altınordu ilçesi oluşturmaktadır. 2017 yılı nüfus verilerine göre Ordu kentinin nüfusu 742.341 kişidir ve Ordu nüfusunun \% 26'sı merkez ilçede yaşamaktadır (Anonim, 2018).

Çalıșmanın konusu olan Altınordu ilçesi 303.6 $\mathrm{km}^{2}$ 'lik yüz ölçüme sahip olup 40 mahalleden oluşmaktadır. İlçenin 22 mahallesi merkezde bulunmaktadır ve toplam yüz ölçümü $2.091 \mathrm{~km}^{2}$ 'dir. 22 merkez mahallenin 20'sinde toplamda 416.575 $\mathrm{m}^{2}$ alana sahip 78 adet park yer almaktadır (Şekil 1). Parklardan 3'ü kıyı parkı, 3'ü koruluk ve 72'si mahalle parkı niteliği taşımaktadır.

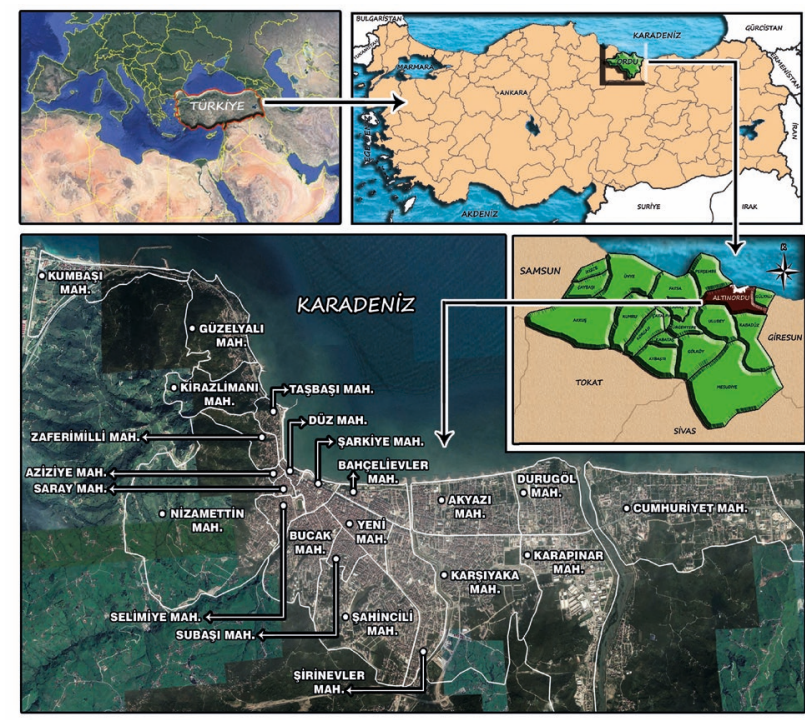

Şekil 1. Ordu kenti Altınordu ilçesi konum ve mahalle sinırları 


\section{Yöntem}

Nüfusu 200.055 kişi olan Altınordu ilçesinde, çalışma kapsamında incelenmiş olan 22 merkez mahallenin toplam nüfusu 172.878 kișidir (Anonim, 2018). Mahalle nüfuslarının 1/1000'i oranı hesaplanarak park alanlarını kullanan 173 kișiye bire bir anket uygulaması yapılmıştır.

Anket çalışması kapsamında; merkez mahallelerde bulunan parkları kullanan kentlilerin, bireysel özellikleri, park tercihleri, parklardan memnuniyet düzeyleri, kullanım sıklıkları, kullanım esnasında karşılaştıkları olumsuzluklar ve alana yönelik beklentileri irdelenmiştir. Aynı zamanda cinsiyet, yaş, medeni durum ve eğitim durumu gibi özellikler ile bireylerin parkları kullanım nedenleri ve parklardan memnuniyet düzeyleri arasında anlamlı bir ilişki olacağı öngörüldüğünden park kullanıcılarının demografik özellikleri hakkında da bilgi alınmıştır.

Anketler SPSS 16.0 paket programı kullanılarak değerlendirilmiștir. Analizlerde tekli değerlerde Frekans, ikili karşılaştırmalarda ise Ki-Kare analizi uygulanmış ve karşılaştırmalar arasında anlamlı bir ilişki ( $\mathrm{p} \leq 0.05$ ) olup olmadığına bakılmıştır.

\section{Bulgular}

Çalışma kapsamında incelenmiş olan 22 merkez mahallenin 19'unda ankete katılım sağlanmıştır. Katılımcıların demografik özelliklerine bakıldığında; \% 54.3'ünün kadın, \% 45.7'sinin erkek ve \% 59'unun evli ve \% 41'inin bekâr olduğu görülmektedir. Evli olan katılımcıların \% 50.3'ünün çocuğu varken, \% 8.7'sinin çocuğu yoktur (Çizelge 1).

Mahalle parkları, açık alanda önemli rekreasyonel işlevleri olan aktivite alanlarıdır. $\mathrm{Bu}$ yüzden mahallenin karakteristik işlevlerine, nüfus büyüklüklerine ve özelliklerine göre düzenlenmeli, mahalle halkının, çocukların ve yaşlıların günlük rekreasyon ihtiyaçlarını karşılayacak donatılar içermelidir (Dil, 2004). Bu durumda parklar planlanırken mahalle halkının aynı anda parkı kullanacağı düşünülmeli, kişi başına düşecek olan park alanı miktarları hesaplanmalı ve parkların mahalleye olan yeterliliklerinin belirlenmesi gerekmektedir. Katılımcıların kullandıkları parkların yeterlilikleri hakkındaki görüşleri Çizelge 2'de verilmiştir.

Yıldızcı (1982)'ya göre mahalle parkları; konutların 400-800 m yakınında olması ve yoğun yerleşim grubuna hizmet etmesi gerekmektedir (Kandemir, 2010). Kullanıcıların parklara kolay ulaşımı ve park alanında ki konforu parkların tercihlerini etkileyen önemli unsurlardandır. Çalışma alanında kullanıcıların en çok tercih ettikleri park ve tercih nedenleri Çizelge 3'de verilmiştir.

Çizelge 1. Anket katılımcılarının demografik özellikleri

\begin{tabular}{cccc}
\hline \multicolumn{2}{c}{ SOSYAL YAPI } & Frekans & Yüzde (\%) \\
\hline \multirow{3}{*}{ Cinsiyet } & Kadın & 94 & 55 \\
& Erkek & 79 & 45 \\
& TOPLAM & 173 & 100 \\
\hline \multirow{4}{*}{ Yaş Grubu } & $15-25$ & 42 & 24.3 \\
& $26-35$ & 81 & 46.8 \\
& $36-55$ & 32 & 18.5 \\
& $56-65+$ & 18 & 10.4 \\
Medeni Durum & TOPLAM & 173 & 100 \\
& Evli & 102 & 59 \\
& Bekâr & 71 & 41 \\
& TOPLAM & 173 & 100 \\
\hline \multirow{4}{*}{ Eğitim Durumu } & Öğrenim Görmedim & 2 & 1.2 \\
& Orta Öğretim & 25 & 14.4 \\
& Lise & 51 & 29.5 \\
& Üniversite & 82 & 47.4 \\
& Üniversite Sonrası & 13 & 7.5 \\
& TOPLAM & 173 & 100 \\
\hline
\end{tabular}

Çizelge 2. Ordu Kenti Altınordu İlçesi park yeterlilikleri

\begin{tabular}{cccc}
\hline Parkların Yeterliliği & Yeterli (\%) & Yetersiz (\%) & Toplam \\
\hline Altınordu geneli & 41.6 & 58.4 & 100 \\
Yaşanılan mahalle & 31.2 & 68.8 & 100 \\
\hline
\end{tabular}

Çizelge 3. Park tercihleri ve tercih nedenleri

\begin{tabular}{ccc}
\hline Parkların tercih nedeni & Mahalle Parkları & Kıyı Parkları \\
\hline Konutlara yakınlık & 20.2 & - \\
Aktivite çeşitliliği & - & 44.4 \\
Merkezi konum & - & 21.4 \\
Mahallede park olmaması & - & 14 \\
\hline TOPLAM (\%) & 20.2 & 79.8 \\
\hline
\end{tabular}

Parklar engelsiz mekân kullanımları açısından değerlendirildiğinde; mahalle parkını kullananların $\%$ 57.1'i, kıyı parklarını kullananların ise \% 35.5' $\mathrm{i}$ özel gereksinimli insanlara (fiziksel engelli, görme engelli, bebek arabalı ebeveynler gibi) yönelik kullanımların olmadığını belirtmiştir. Mahalle ve kıyı parklarına yönelik memnuniyet düzeyleri incelendiğinde katılımcıların \% 16.8'i çok memnun olduğunu, \% 60.6'sı memnun olduğunu ve \% 22.6'sı ise hiç memnun olmadığını belirtmiştir (Çizelge 4). Park alanlarının yıl boyu kullanılacak şekilde alt ve üst yapı elemanlarına sahip olması gerekmektedir. Alanların drenajı, zemini, içerisinde barındırdığı fonksiyonlar, kapasitesi, bakım ve hizmet üniteleri yıl boyu kullanımlara uygun şekilde donatılmalıdır (Kandemir, 2010). 
Çizelge 4. Tercih edilen park ve memnuniyet düzeyi

\begin{tabular}{|c|c|c|c|c|c|}
\hline \multirow{2}{*}{ Tercih Edilen Park } & \multicolumn{3}{|c|}{ Memnuniyet Düzeyi } & \multirow{2}{*}{ TOPLAM (\%) } & \multirow{2}{*}{ P Değeri } \\
\hline & Hiç Memnun Değilim & Memnunum & Çok Memnunum & & \\
\hline Mahalle & 8.1 & 9.2 & 2.9 & 20.2 & \\
\hline Kiyl & 14.5 & 51.4 & 13.9 & 79.8 & $0.021(\mathrm{~L})$ \\
\hline TOPLAM (\%) & 22.6 & 60.6 & 16.8 & 100 & \\
\hline
\end{tabular}

Mahalle parklarını kullanan katılımcıların \% 42'si parkları her mevsim kullanabildiklerini, \% 58'i ise kullanamadıklarını ifade etmiştir. Kıyı parklarının mevsimsel kullanımlarına bakıldığında ise katılımcların \% 49,2'si her mevsim kullanılabildiğini, \% 50.9'u ise kullanamadığını belirtmiștir.

Parkların kullanıcıların istek ve ihtiyaçlarına göre halka hizmet vermesi gerekmektedir. Bu nedenle park alanlarının planlama aşamalarında kullanıcılara huzur ve güven veren, rahatlamalarına, dinlenmelerine ve alandan memnun kalmalarını sağlayacak tasarım ve alan kullanımlarının öncelikli olarak yer verilmesi gerekmektedir (Kart, 2002).
Parkları kullanım sırasında katılımcıların \% 82.7'si kullandıkları parkta kendilerini güvenli ve huzurlu, $\%$ 17.3'ü güvensiz ve tedirgin hissetmektedir. Kullanıcıların parklarda hissettikleri duygular ve alanda geçirdikleri zaman arasında yapılmış olan analize göre anlamlı ( $\mathrm{p} \leq$ 0.05) bir ilişki bulunmaktadır (Çizelge 5).

Güvenli ve huzurlu hissedilen parklarda geçirilen sürenin az olmasını katılımcılar alanlarda aydınlatma, donatı ve alan kullanımlarında (piknik, spor, dinlenme alanı, vb.) yaşanan eksikliklerden kaynaklı olduğunu dile getirmiştir.

Çizelge 5. Parklarda hissedilen duygular ve parklarda geçirilen süre

\begin{tabular}{cccccc}
\hline \multirow{2}{*}{ Hissedilen Duygu } & \multicolumn{3}{c}{ Geçirilen Zaman } & \multirow{2}{*}{ TOPLAM (\%) } & \multirow{2}{*}{ P Değeri } \\
\cline { 2 - 4 } & $0-1(\%)$ & $1-2(\%)$ & $2-3+(\%)$ & 82.7 & \\
Güvenli ve Huzurlu & 22.0 & 54.9 & 5.8 & & \multirow{2}{*}{$0.046(\mathrm{~L})$} \\
Güvensiz ve Tedirgin & 8.6 & 8.1 & 0.6 & & 17.3 \\
TOPLAM (\%) & 30.6 & 63.0 & 6.4 & & 100 \\
\hline
\end{tabular}

Parkların kullanıldı̆̆ı günler bakımından anketler değerlendirildiğinde katılımcıların \% 24.8'i hafta içi parkları kullanırken \% 75.2'si hafta sonunu tercih etmektedir (Çizelge 4). Parkların kullanıldığı gün ve meslek arasında ilişkiye bakıldığında memur, işçi, ev hanımı, emekli ve işsiz olan kullanıcıların gün tercihlerinde anlamlı ( $\mathrm{p} \leq \mathrm{0.05}$ ) bir ilişki olduğu görülmektedir (Çizelge 6). Çalışan kullanıcıların parkları daha çok hafta sonu tercih ettikleri, ev hanımı, emekli ve işsiz olanların ise parkları daha çok hafta içi kullandıkları görülmüştür.

Parkları kullanan kentlilerin medeni durumları ve kullanım amaçları arasında anlamlı ( $\mathrm{p} \leq$ 0.05) bir ilişki bulunmaktadır. Evli olan kullanıcıların \% 20.8'i çocukları eğlendirmek, piknik yapmak ve manzarası için parkları kullanırken, bekâr olan kullanıcıların \% 23.7'si parkları spor yapmak, hava almak ve manzara amacı ile kullanmaktadır (Çizelge 7).

Katılımcıların parkları kullanım sırasında alanlara yönelik rahatsız oldukları faktörler Çizelge 8'de verilmiştir. Anket katılımcılarına parkları kullanımı esnasında onları kisıtlayan bir faktör bulunup bulunmadığı sorulduğunda katılımcıların \% 50.3'ü kullanımı kısıtlayan her hangi bir faktör bulunmadığını ifade ederken, \% 49.8'i kullanımı kısıtlayan bazı faktörler olduğunu söylemiștir. Parkta kullanımı kısıtlayan faktörler olduğunu belirten (\% 49.8) kullanıcılara bu kısitlamaların neler olduğu sorulduğunda vermiş oldukları yanıtlar Çizelge 8'de verilmiştir.

Katılımcılara parkların kullanıcı beklentilerini karşılayıp karşılamadığı sorulmuştur. Bu soruya karşılık \% 57.2'lik bir oranla beklentilerin karşılandığı belirtilirken, \% 42.8'lik bir oranla beklentilere yanıt vermediği belirtilmiș ve parklara yönelik Çizelge 9'da belirtilen düzenlemelerin yapılması gerektiği ifade edilmiştir.

Yapılan analiz sonucunda kullanıcıların parklardan beklentileri ile tasarım elemanlarından memnun olup olmadıkları arasında anlamlı ( $\mathrm{p} \leq 0.05)$ bir ilişki olduğu bulunmuştur. Kullanıcıların parklarda bulunan donatı elemanlarına yönelik memnuniyet düzeylerine bakıldığında; \% 59'unun memnun olduğu, \% 41'inin ise memnun olmadığı ortaya çıkmıştır. WC bakımından ise kullanıcıların \% 90.8'inin memnun olmadığı görülmektedir (Çizelge 10). 
Çizelge 6. Meslek grupları ve parkların kullanıldıkları gün arasındaki ilişki

\begin{tabular}{|c|c|c|c|c|}
\hline \multirow{2}{*}{ Meslek Grupları } & \multicolumn{2}{|c|}{ Kullanılan Gün } & \multirow{2}{*}{ TOPLAM (\%) } & \multirow{2}{*}{ P Değeri } \\
\hline & Hafta İçi (\%) & Hafta Sonu (\%) & & \\
\hline Esnaf & 1.2 & 2.3 & 3.5 & $0.636(\mathrm{~L})$ \\
\hline Memur & 1.7 & 18.5 & 20.2 & $0.013(\mathrm{P})$ \\
\hline İşçi & 0.6 & 16.8 & 17.4 & $0.003(\mathrm{P})$ \\
\hline Ev Hanımı & 9.8 & 8.1 & 17.9 & $0.000(\mathrm{P})$ \\
\hline Serbest Meslek & 0.6 & 7.5 & 8.1 & $0.073(\mathrm{~L})$ \\
\hline Öğrenci & 4.0 & 19.7 & 23.7 & $0.187(\mathrm{P})$ \\
\hline Emekli & 5.2 & 1.7 & 6.9 & $0.000(\mathrm{~L})$ \\
\hline İşsiz & 1.7 & 0.6 & 2.3 & $0.033(\mathrm{~L})$ \\
\hline TOPLAM (\%) & 24.8 & 75.2 & 100 & $0.000(\mathrm{~L})$ \\
\hline
\end{tabular}

Çizelge 7. Medeni Durum ve Parkların Kullanım Amaçları

\begin{tabular}{cccc}
\hline Kullanım Amacı & \multicolumn{2}{c}{ Medeni Durum } \\
\cline { 2 - 4 } Evli (\%) & \multicolumn{2}{c}{ Bekâr (\%) } \\
\hline Çocukları Eğlendirmek, Piknik Yapmak, Manzara & 20.8 & 5.2 & 26 \\
Spor Yapmak, Hava Almak, Manzara & 15.0 & 23.7 & 38.7 \\
Çocukları Eğlendirmek, Spor Yapmak, Hava Almak & 9.8 & 2.3 & 12.1 \\
Piknik Yapmak, Hava Almak, Manzara & $0.00(\mathrm{~L})$ & 9.8 & 23.2 \\
TOPLAM (\%) & 59.4 & 41.0 & 100 \\
\hline
\end{tabular}

Çizelge 8. Kullanıcıların park tercihleri ve kullanım esnasında rahatsızlık duyulan faktörler

\begin{tabular}{|c|c|c|c|}
\hline \multirow{2}{*}{ Rahatsızlık Duyulan Faktörler } & \multicolumn{2}{|c|}{ Tercih Edilen Park } & \multirow{2}{*}{ TOPLAM (\%) } \\
\hline & Mahalle (\%) & Kiyı (\%) & \\
\hline Toz / Gürültü / Çöp & 4 & 9.9 & 13.9 \\
\hline Toz / Gürültü / Kullanıcı Yoğunluğu & 4 & 15.6 & 19.6 \\
\hline Toz / Çöp / Tasarım Yetersizliği & 6.4 & 13.3 & 19.7 \\
\hline Gürültü / Otopark Sorunu / Tasarım Yetersizliği & 4.1 & 20.2 & 24.3 \\
\hline Çöp / Gürültü / Kullanıcı Yoğunluğu & 1.7 & 20.8 & 22.5 \\
\hline TOPLAM (\%) & 20.2 & 79.8 & 100 \\
\hline
\end{tabular}

Çizelge 9. Kullanıcıların beklentileri

\begin{tabular}{cc}
\hline Beklentiler & $\begin{array}{c}\text { Yüzde } \\
\text { Değeri (\%) }\end{array}$ \\
\hline Çocuk oyun ve spor alanlarının arttırılması & 14 \\
Oturma birimleri ve gölgeliklerin arttırılması & 41 \\
Aydınlatmaların arttırılması ve güvenliğin sağlanması & 18 \\
WC ve Çeşmelerin Arttırılması & 5 \\
Yeşil Alanlar ve Gölge Yapıcı Bitkilerin Arttırılması & 5 \\
Temizlik ve Bakımın Arttırılması & 23 \\
TOPLAM & 100 \\
\hline
\end{tabular}

\section{Sonuç ve Öneriler}

$\mathrm{Bu}$ çalışma kapsamında Ordu kenti, Altınordu ilçesinde bulunan parkların kullanıcıların beklentilerini ne düzeyde karșıladıklarını belirlemek amaçlanmıştır.

Bir park alanının estetik ve fonksiyonel olmasında en önemli etken alan içerisinde bulunan donatıların çevre ile uyumlu, algılanabilir, insan ergonomisine uygun ve ihtiyaçlara cevap verecek nitelikte olmasına bağlıdır. Bu kapsamda çalışma alanlarında kullanılmış olan kentsel donatı elemanları incelenmiş ve kullanıcı görüşleri değerlendirilmiştir. Gözlemler ve yapılan ölçümler sonucunda donatı elemanlarının TS 12576 standartlarına uygun ve insan antropometrisine uyumlu ölçülere sahip olduğu tespit edilmiştir. Ancak estetik kaygılarla yapılan bazı donatı elemanlarının fonksiyonellikten uzak olduğu görülmektedir. Ankete katılan kullanıcıların \% 79.3'ü parklarda bulunan kapalı mekânları ve üst örtü elemanlarını yetersiz bulduklarını belirtmesi bu durumu destekler niteliktedir.

Parkların gece algılanabilmesi ve kullanıcıların alan içerisinde güvende olabilmeleri için aydınlatma elemanları büyük önem taşımaktadır. Ankete katılan kadın kullanıcıların \% 17.2'si ile erkek kullanıcıların $\% \quad 15.2^{\prime}$ si olmak üzere \% 32.4'ü aydınlatma eksikliğinin kullanımı kısıtlayan bir faktör olduğunu belirtmiştir.

Tayfun Gürsoy parkı, Akyazı kıyı parkı ve Yüksel Poyraz Mahalle parkı olmak üzere üç parkta WC bulunmakta diğerlerinde bulunmamaktadır. Anket sonuçlarına göre kullanıcıların \% 90.8'i WC ler'den memnun değildir. Anket sonuçlarına göre kullanıcıların \% 44.5'inin parklarda bulunan ve su ihtiyacını karşılamaya yönelik kullanılan 
çeşmelerden memnun olmadıkları ortaya çıkmıştır. Park kullanıcılarının anketlere verdiği cevaplar incelendiğinde bu yetersizliğin kullanıcılar açısından sorun oluşturduğu görülmüştür. Anket sonuçlarına göre parkların beklentilerini karşılamadığını belirten kullanıcların \% 41'i parklarda bulunan oturma birimleri ve gölgelik alanların arttırılması gerektiğini belirtmiştir.

Çizelge 10. Kullanıcıların parklardan beklentileri ve parklarda bulunan tasarım elemanlarına yönelik memnuniyet dereceleri

\begin{tabular}{|c|c|c|c|c|c|c|}
\hline \multirow[b]{2}{*}{ Beklentilerinizi Karşılıyor Mu? } & \multicolumn{5}{|c|}{ Çocuk Oyun Elemanları } & \multirow[b]{2}{*}{$\begin{array}{l}\overline{\bar{D}} \\
\stackrel{100}{0} \\
0 \\
a\end{array}$} \\
\hline & 능 & 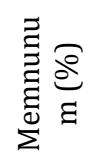 & $\stackrel{\substack{0 \\
0}}{\varrho}$ & \multicolumn{2}{|c|}{ 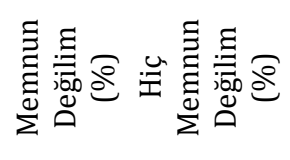 } & \\
\hline Evet & 4.6 & 28.9 & 21.4 & 2.3 & - & \\
\hline Hayır & 1.7 & 15.6 & 15.0 & 6.4 & 4.1 & $0.000(\mathrm{~L})$ \\
\hline TOPLAM (\%) & 6.3 & 44.5 & 36.4 & 8.7 & 4.1 & \\
\hline \multicolumn{7}{|c|}{ Spor Alanları } \\
\hline Evet & 3.5 & 30.6 & 12.7 & 8.7 & 1.7 & \multirow{3}{*}{$0.003(\mathrm{~L})$} \\
\hline Hayır & 1.2 & 17.9 & 5.2 & 11.6 & 6.9 & \\
\hline TOPLAM (\%) & 4.7 & 48.5 & 17.9 & 20.3 & 8.6 & \\
\hline \multicolumn{7}{|c|}{ Oturma Birimleri } \\
\hline Evet & 5.2 & 35.2 & 2.3 & 13.3 & 1.2 & \multirow{3}{*}{$0.000(\mathrm{~L})$} \\
\hline Hayır & - & 11.0 & 1.2 & 23.1 & 7.5 & \\
\hline TOPLAM (\%) & 5.2 & 46.2 & 3.5 & 36.4 & 8.7 & \\
\hline \multicolumn{7}{|c|}{ Döșeme Kaplamaları } \\
\hline Evet & 4.6 & 32.9 & 7.0 & 11.0 & 1.7 & \multirow{3}{*}{$0.000(\mathrm{~L})$} \\
\hline Hayır & 0.6 & 13.3 & 7.5 & 12.1 & 9.3 & \\
\hline TOPLAM (\%) & 5.2 & 46.2 & 14.5 & 23.1 & 11.0 & \\
\hline \multicolumn{7}{|c|}{ Aydınlatma Elemanları } \\
\hline Evet & 6.3 & 33.5 & 11.0 & 5.2 & 1.2 & \multirow{3}{*}{$0.000(\mathrm{~L})$} \\
\hline Hayır & 0.6 & 16.8 & 4.6 & 15.6 & 5.2 & \\
\hline TOPLAM (\%) & 6.9 & 50.3 & 15.6 & 20.8 & 6.4 & \\
\hline \multicolumn{7}{|c|}{ Çöp Kutuları } \\
\hline Evet & 4.0 & 29.5 & 5.8 & 14.4 & 3.5 & \multirow{3}{*}{$0.039(\mathrm{P})$} \\
\hline Hayır & 2.9 & 15.6 & 2.3 & 13.9 & 8.1 & \\
\hline TOPLAM (\%) & 6.9 & 45.1 & 8.1 & 28.3 & 11.6 & \\
\hline \multicolumn{7}{|c|}{ Gölgelikler } \\
\hline Evet & 3.0 & 19.0 & 7.5 & 21.3 & 6.4 & \multirow{3}{*}{$0.002(\mathrm{~L})$} \\
\hline Hayır & - & 7.6 & 4.0 & 19.7 & 11.6 & \\
\hline TOPLAM (\%) & 3.0 & 26.6 & 11.5 & 41.0 & 17.9 & \\
\hline \multicolumn{7}{|c|}{ Yürüyüș Yolu } \\
\hline Evet & 11.0 & 40.4 & 2.9 & 2.3 & 0.6 & \multirow{3}{*}{$0.000(\mathrm{~L})$} \\
\hline Hayır & 4.0 & 24.9 & 0.6 & 7.5 & 5.8 & \\
\hline TOPLAM (\%) & 15.0 & 65.3 & 3.5 & 9.8 & 6.4 & \\
\hline \multicolumn{7}{|c|}{ Su Elemanı } \\
\hline Evet & 1.7 & 15.0 & 20.8 & 13.9 & 5.8 & \multirow{3}{*}{$0.025(\mathrm{~L})$} \\
\hline Hayır & 0.6 & 5.2 & 12.2 & 17.9 & 6.9 & \\
\hline TOPLAM (\%) & 2.3 & 20.2 & 33.0 & 31.8 & 12.7 & \\
\hline \multicolumn{7}{|c|}{ Yeșil Alanlar } \\
\hline Evet & 6.9 & 41.6 & 2.3 & 5.2 & 1.2 & \multirow{3}{*}{$0.038(\mathrm{~L})$} \\
\hline Hayır & 3.5 & 24.2 & 2.9 & 11.0 & 1.2 & \\
\hline TOPLAM (\%) & 10.4 & 65.8 & 5.2 & 16.2 & 2.4 & \\
\hline \multicolumn{7}{|c|}{ W.C } \\
\hline Evet & - & 9.2 & - & 15.6 & 32.4 & \\
\hline Hayır & - & - & - & 16.2 & 26.6 & $0.001(\mathrm{P})$ \\
\hline TOPLAM (\%) & - & 9.2 & - & 31.8 & 59.0 & \\
\hline
\end{tabular}


Kullanıcılar tarafından \% 23'lük bir oranla temizlik eksikliği, parkların kullanımını kısıtlayan faktörlerden biri olarak ifade edilmiştir. Yapılan literatür araștırmaları ve alan analizleri sonucunda elde edilen bulgular doğrultusunda, Ordu kenti, Altınordu ilçesinde bulunan parkların kent kimliğine katkı sağlayan daha estetik ve fonksiyonel olabilmeleri adına yapılabilecekler şu şekilde siralanabilir;

Üst örtü elemanlarında daha sık lata kullanımı, sarılıcı-tırmanıcı bitkilerle kombine edilmesi ve sayılarının arttırılması ile iklime bağlı kısıtlayıcıları ortadan kaldırmak mümkün olacaktır. Kent-mekâninsan arasındaki bağı güçlendirmek ve kullanıcıların parklara yönelik memnuniyet düzeylerini artırmak adına eksikliklerin giderilmesi olumlu bir gelişme olacaktır.

Görmeyi ve görünmeyi zorlaștıran kör nokta oluşumlarını engellemek adına aydınlatmaların sayısının arttırılması, ağaçlardan dolayı aydınlatma eksikliği olan parklarda yürüyüş yolu aydınlatmaları kullanılarak parkların zeminlerinin görünür hale getirilmesi, hem alan içi güvenliğine yardımcı olacak hem de alanların gece aktif kullanımına katkı sağlayacaktır.

Parklarda kullanıcıların hiç memnun olmadıkları durum olarak belirlenmiş olan WC eksikliğinin önüne geçilmesi ve bu kapsamda kullanıcı memnuniyetinin artırılmasını sağlamak adına parkların mevcut durumları ve alan büyüklüklerinin değerlendirilip WC yapılması ya da parklara yakın alanlarda ki umuma açık WC sayılarının artırılması uygun olacaktır.

Su elemanı parkların vazgeçilmez bir unsurudur. Gerek görsel gerek fonksiyonel olarak parkların kalitesini ve kullanıcıların parklara yönelik memnuniyetlerini artırmak için parklarda su elemanlarının oluşturulması olumlu bir gelişme olacaktır.

Çocuk oyun alanlarında karşılaşılan sorunların önüne geçmek için geleceğimiz olan çocukların gelişimlerine katkı sağlayan oyun alanlarının daha dikkatli oluşturulması, temizliğinin ihmal edilmemesi, onlara zarar verecek yapısal ve bitkisel uygulamalardan kaçınılması ve alanların özenli bir şekilde tesis edilmesi gerekmektedir.

Çevre kirliliklerinin önüne geçilebilmesi için kullanılacak olan çöp kutularının konumlandırılmasinda standartlara uyulması gerekmektedir.

\section{Kaynaklar}

Akova, İ., 2012. "Turizm Coğrafyası ve Planlama”. Turizm Coğrafyası. (Editör: Doç. Dr. Semra Günay). ss: 2-36, Eskişehir: Anadolu Üniversitesi Yayınları.

Anonim, 2012. Ordu İli Doğa Master Planı 2013-2023. T.C. Orman ve Su İşleri Bakanlığı, Doğa Koruma ve Milli Parklar Genel Müdürlügü. XI. Bölge Müdürlügü Ordu Şube Müdürlüğü. Ordu.

Anonim, 2018. Türkiye İstatistik Kurumu. https://biruni.tuik.gov.tr/medas (Erişim Tarihi: 14.11.2018).

Anonim, 2019. TS 12576 Şehir içi yollar - Kaldırım ve yaya geçitlerinde ulaşılabilirlik için yapısal önlemler ve işaretlemelerin tasarım kuralları. Türk Standartları Enstitüsü, Ankara

Dil, M., 2004. İstanbul'un yeşil alan sisteminin, planlama kriterleri açısından irdelenmesi. Yüksek Lisans Tezi, İstanbul Teknik Üniversitesi, Fen Bilimleri Enstitüsü, İstanbul.

Ersoy, M., 1994. Kentsel alan kullanım normları. Ortadoğu Teknik Üniversitesi Mimarlık Fakültesi Basım İşbirliği, No: 92.02, Ankara, 301s.

Gürsoy, B.D., 2018. Küçük ölçekli parkların etki alanlarına kattığı değerlerin ve kullanım potansiyellerinin irdelenmesi İstanbul ili Beşiktaş İlçesi örneği. Yüksek Lisans Tezi, İstanbul Teknik Üniversitesi, Fen Bilimleri Enstitüsü, Kentsel Tasarım Anabilim Dalı, İstanbul.

Kahraman, Z.E., 2017. Kent sosyolojisi: Kent planlama, Editörler: Özdemir, S.S., Sarı, Ö.B., \& Uzun, N., İmge Kitapevi Yayınları, Ankara, 329-358.

Kart, N., 2002. Emirgan parkında kullanıcıların memnuniyet derecelerinin değerlendirilmesi. Yüksek Lisans Tezi, İstanbul Üniversitesi, Fen Bilimleri Enstitüsü, Peyzaj Mimarlığı Anabilim Dalı, İstanbul.

Kandemir, R.V., 2010. Kamusal alan içerisinde mahalle parkları ve bir mahalle parkı tasarım rehberi düşüncesi. Yüksek Lisans Tezi, Mimar Sinan Güzel Sanatlar Üniversitesi, Fen Bilimleri Enstitüsü, Şehir ve Bölge Planlama Anabilim Dalı, İstanbul.

Nasuh, D., 1993. Kent parklarının nitelikleri ve Ankara örneğinin irdelenmesi. Yüksek Lisans Tezi, Ankara Üniversitesi, Fen Bilimleri Enstitüsü, Peyzaj Mimarlığı Anabilim Dalı, Ankara. 
Sherer, P.M., 2003. Why America needs more city parks and open space. The Trust for Public Land, 1-31.
Yıldızcı, A. C. (1982). Kentsel yeşil alan planlaması ve İstanbul örneği. Doçentlik Tezi, İTÜ Mimarlık Fakültesi, İstanbul. 